\title{
De-mystifying the Epigenetic Free for All: Pharmacophore Modeling for Epigenetic Cancer Therapy
}

Viviane Rösner de Almeida1 ${ }^{1}$, Algemir Lunardi Brunetto ${ }^{1,2,3,4}$, Gilberto Schwartsmann ${ }^{1,3,5}$, Rafael Roesler1,2,3,6 and Ana Lucia Abujamra',2,3*

${ }^{1}$ Cancer Research Laboratory, University Hospital Research Center (CPE-HCPA)

${ }^{2}$ Children's Cancer Institute (ICI-RS)

${ }^{3}$ National Institute for Translational Medicine (INCT-TM)

${ }^{4}$ Department of Pediatrics, School of Medicine, Federal University of Rio Grande do Sul

${ }^{5}$ Department of Internal Medicine, School of Medicine, Federal University of Rio Grande do Sul

${ }^{6}$ Laboratory of Molecular Neuropharmacology, Institute of Basic Health Sciences, Federal University of Rio Grande do Sul

\begin{abstract}
Epigenetic regulators have quickly become one of the most widely studied therapeutic agents for a vast array of diseases, making histone deacetylase inhibitors (HDIs) and DNA methyl-transferase (DNMT) inhibitors commonly used molecules in pre-clinical and clinical anti-cancer studies. Their ability to regulate gene expression and to potentiate the effects of other chemotherapeutic drugs has put HDIs and DNMT inhibitors in the spotlight not only as single agents, but also as combined therapy. The plethora of HDIs and DNMT inhibitors available nowadays has led to promising results in Phase I, II and III clinical oncology studies. While it was first believed that these molecules would all have an additive or synergistic effect when combined with the classical chemotherapeutic drugs available, our group and others have shown that epigenetic regulators potentiate the effects of some, but not all, anti-cancer molecules. Pharmacophore modeling may therefore serve the purpose to optimize pre-clinical research and to develop more efficient and targeted therapies incorporating epigenetic regulators.
\end{abstract}

Epigenetic regulators have quickly become one of the most widely studied therapeutic agents for a vast array of diseases, making histone deacetylase inhibitors (HDIs) and DNA methyl-transferase (DNMT) inhibitors commonly used molecules in pre-clinical and clinical anticancer studies [1-4]. Their ability to regulate gene expression and to potentiate the effects of other pharmaceutical drugs has put HDIs and DNMT inhibitors in the spotlight not only as single agents, but also as combined therapy. The plethora of HDIs (Table 1 included as supplementary data) and DNMT inhibitors (Table 2 (included as supplementary data)) available nowadays have led to promising results in Phase I, II and III clinical oncology studies. Results not only show their potential as cytostatic and cytotoxic agents, but also as chosen agents for combined therapy because of their ability to potentiate classical drugs utilized to treat the disease, allowing for the same cytotoxic effect at lower doses $[5,6]$.

While it was first believed that these molecules would all have an additive or synergistic effect when combined with the classical chemotherapeutic drugs available, our group and others have shown that epigenetic regulators potentiate the effects of some, but not all, anti-cancer molecules [6-8]. Since epigenetic regulators exert their effect mainly on the DNA conformation, allowing for otherwise silenced genes to be expressed, and vice-versa, it was first postulated that they would potentiate the effects of the classical chemotherapeutic drugs that interact directly with the DNA. This has proven not to be the case, making screening for additive or synergistic effects in vitro a necessity before designing any in vivo experiments or feasibility studies. Pharmacophore modeling may therefore serve the purpose to optimize pre-clinical research and to develop more efficient and targeted therapies incorporating epigenetic regulators.

Ehrlich first defined a pharmacophore as "a molecular framework that carries the essential features responsible for a drug's biological activity" [9]. This definition evolved twenty years to its current definition: "an ensemble of steric and electronic features that is necessary to ensure the optimal supramolecular interactions with a specific biological target and to trigger, or block, its biological response" [10]. Pharmacophore models can be established either as ligand-based or structure-based. Ligand-based models are usually utilized when a macromolecular target structure is not available, and therefore a set of active molecules are superposed and their common chemical features, essential for their bioactivity, are then extracted by a computer software. Structure-based pharmacophore models utilizes the three-dimensional structure of a macromolecular target or, at times, a target- ligand complex, and probes possible interaction points between target and ligand [11]. Both models present advantages and disadvantages that are best described Yang's review [12], the most prominent disadvantage being the high cost involved in developing and analyzing the algorithms necessary for the optimization of drug design. Nonetheless, as exemplified by Yoo and Medina-Franco [13], pharmacophore modeling has been used to predict the activity of DNMT inhibitors, elucidating the interactions that allow for their mechanism of action and allowing for a more efficient screening of novel inhibitors. Even though there are significant costs involved with pharmacophore modeling, the employment of this technique reduces significantly the time spent on experimental drug design, indirectly reducing costs as well [14]. Therefore, if a multi-disciplinary effort is made to optimize and shorten the time necessary for the drug design of these inhibitors, considerable clinical advances will also be achieved.

*Corresponding author: Ana Lucia Abujamra, PhD, Children's Cancer Institute Cancer Research Laboratory, University Hospital Research Center, (CPE-HCPA) R. Ramiro Barcelos, 2350, 2nd Floor, Porto Alegre, RS 90035-903 Brazil, Tel: +55 51 3359-7616; E-mail: aabujamra@hcpa.ufrgs.br

Received June 25, 2011; Accepted June 27, 2011; Published June 29, 2011

Citation: de Almeida VR, Brunetto AL, Schwartsmann G, Roesler R, Abujamra AL (2011) De-mystifying the Epigenetic Free for All: Pharmacophore Modeling for Epigenetic Cancer Therapy. Pharm Anal Acta 2:102e. doi:10.4172/2153 2435.1000102e

Copyright: (C) 2011 de Almeida VR, et al. This is an open-access article distributed under the terms of the Creative Commons Attribution License, which permits unrestricted use, distribution, and reproduction in any medium, provided the original author and source are credited. 
Citation: de Almeida VR, Brunetto AL, Schwartsmann G, Roesler R, Abujamra AL (2011) De-mystifying the Epigenetic Free for All: Pharmacophore Modeling for Epigenetic Cancer Therapy. Pharm Anal Acta 2:102e. doi:10.4172/2153-2435.1000102e

\section{Conflicts of Interest}

The authors declare no conflicts of interest that may have influenced the discussion therein.

\section{Acknowledgements}

The authors are supported by the Children's Cancer Institute (ICl-RS), the National Council for Scientific and Technological Development (CNPq); the National Institute for Translational Medicine (INCT-TM); the South American Office for Anticancer Drug Development (SOAD); and HCPA-FIPE.

\section{References}

1. Mund C, Lyko F (2010) Epigenetic cancer therapy: Proof of concept and remaining challenges. Bioessays 32: 949-57.

2. Kwa FA, Balcerczyk A, Licciardi P, El-Osta A, Karagiannis TC (2011) Chromatin modifying agents - the cutting edge of anticancer therapy. Drug Discov Today 16: 543-7.

3. Abujamra AL, Dos Santos MP, Roesler R, Schwartsmann G, Brunetto AL (2010) Histone deacetylase inhibitors: a new perspective for the treatment of leukemia. Leuk Res 34: 687-95.

4. Ren J, Singh BN, Huang Q, Li Z, Gao Y, et al. (2011) DNA hypermethylation as a chemotherapy target. Cell Signal 23: 1082-93.

5. Lu Z, Jia J, Di L, Song G, Yuan Y, et al. (2011) DNA methyltransferase inhibitor CDA-2 synergizes with high-dose thiotepa and paclitaxel in killing breast cancer stem cells. Front Biosci (Elite Ed) 3: 240-9.

6. dos Santos MP, Schwartsmann G, Roesler R, Brunetto AL, Abujamra AL (2009) Sodium butyrate enhances the cytotoxic effect of antineoplastic drugs in human lymphoblastic T-cells. Leuk Res 33: 218-21.

7. Bangert A, Häcker S, Cristofanon S, Debatin KM, Fulda S (2011) Chemosensitization of glioblastoma cells by the histone deacetylase inhibitor MS275. Anticancer Drugs 22: 494-9.

8. Cai W, Maldonado NV, Cui W, Harutyunyan N, Ji L, et al. (2010) Activity of irinotecan and temozolomide in the presence of O6-methylguanine-DNA methyltransferase inhibition in neuroblastoma pre-clinical models. $\mathrm{Br} \mathrm{J}$ Cancer 103: $1369-79$.

9. Ehrlich P (1909) Ueber den jetzigen Stand der Chemotherapie. Ber Dtsch Chem Ges 42: 17-47.

10. Wermuth CG, Ganellin CR, Lindberg P, Mitscher LA (1998) Glossary of terms used in medicinal chemistry (IUPAC Recommendations 1998). Pure Appl Chem 70: 1129-1143.

11. Dror O, Shulman-Peleg A, Nussinov R, Wolfson HJ (2006) Predicting Molecular Interactions In Silico: I. An Updated Guide to Pharmacophore Identification and its Applications to Drug Design. Frontiers in Medicinal Chemistry 551-584.

12. Yang SY (2010) Pharmacophore modeling and applications in drug discovery: challenges and recent advances. Drug Discov Today 15: 444-50.

13. Yoo J, Medina-Franco JL (2011) Homology modeling, docking and structurebased pharmacophore of inhibitors of DNA methyltransferase. J Comput Aided Mol Des [Epub ahead of print].

14. Guner OF (2005) The impact of pharmacophore modeling in drug design. IDrugs 8: 567-72

15. Kwon HJ, Owa T, Hassig CA, Shimada J, Schreiber SL (1998) Depudecin induces morphological reversion of transformed fibroblasts via the inhibition of histone deacetylase. PNAS 95: 3356-3361.

16. Yuanyuan L, Trygve OT (2010) Impact on DNA methylation in cancer prevention and therapy by bioactive dietary components. Curr Med Chem 17: 2141-2151.

17. Wen WM, Alex AA (2009) Novel Agents on the Horizon for Cancer Therapy. Ca Cancer J Clin 59: 111-137.

18. Gravina GL, Festuccia C, Marampon F, Popov MV, Pestell RG, et al. (2010) Biological rationale for the use of DNA methyltransferase inhibitors as new strategy for modulation of tumor response to chemotherapy and radiation. Molecular Cancer 9: 305.

19. Lin J, Gilbert J, Rudek MA, Zwiebel JA, Gore S, et al. (2009) A phase I dosefinding study of 5-azacytidine in combination with sodium phenylbutyrate in patients with refractory solid tumors. Clin Cancer Res 15: 6241-6249.
20. Masetti R, Serravalle S, Biagi C, Pession A (2011) The Role of HDACs Inhibitors in Childhood and Adolescence Acute Leukemias. J Biomed Biotechnol [Epub]

21. Griffiths EA, Gore SD (2008) DNA methyltransferase and histone deacetylase inhibitors in the treatment of myelodysplastic syndromes. Semin Hematol 45 23-30.

22. Younes A, Buglio D (2010) Histone deacetylase inhibitors in Hodgkin lymphoma. Invest New Drugs 28: S21-S27.

23. Ghoshal K, Bai S (2007) DNA methyltransferases as targets for cancer therapy Drugs Today (Barc) 43: 395-422.

24. Federico M, Bagella L (2011) Histone Deacetylase Inhibitors in the Treatment of HematologicalMalignancies and Solid Tumors. J Biomed Biotechnol [Epub].

25. Cheng JC, Weisenberger DJ, Gonzales FA, Liang G, Xu GL, et al. (2004) Continuous zebularine treatment effectively sustains demethylation in human bladder cancer cells. Mol Cell Biol 24: 1270-1278.

26. Zhu X, Yuehua MA, Liu D (2010) Novel agents and regimens for acute myeloid leukemia: 2009 ASH annual meeting highlights. J Hematol Oncol 3: 17.

27. Flotho C, Claus R, Batz C, Schneider M, Sandrock I, et al. (2009) The DNA methyltransferase inhibitors azacitidine, decitabine and zebularine exert differential effects on cancer gene expression in acute myeloid leukemia cells. Leukemia 23: 1019-1028.

28. Teicher BA (2010) Combinations of PARP, hedgehog and HDAC inhibitors with standard drugs. Current Opinion in Pharmacology 10: 397-404.

29. Brueckner B, Boy RG, Siedlecki P, Musch T, Kliem HC, et al. (2005) Epigenetic reactivation of tumor suppressor genes by a novel smallmolecule inhibitor of human DNA methyltransferases. Cancer Res 65: 6305-6311.

30. Villar-Garea A, Fraga MF, Espada J, Esteller M (2003) Procaine is a DNAdemethylating agent with growth-inhibitory effects in human cancer cells Cancer Res 63: 4984-4989.

31. Kristensen LS, Nielsen HM, Hansen LL (2009) Epigenetics and cance treatment. Eur J Pharmacol 625: 131-142.

32. Lee BH, Yegnasubramanian S, Lin X, Nelson WG (2005) Procainamide is a specific inhibitor of DNA methyltransferase I. J Biol Chem 280: 40749-40756.

33. Jatoi A, Ellison N, Burch PA, Sloan JA, Dakhil SR, et al. (2003) A phase II tria of green tea in the treatment of patients with androgen independent metastatic prostate carcinoma. Cancer 97: 1442-1446.

34. Sebova K, Fridrichova I (2010) Epigenetic tools in potential anticancer therapy. Anti-Cancer Drugs 21: 565-577.

35. Plummer R, Vidal L, Griffin M, Lesley M, de Bono J, et al. (2009) Phase I study of MG98, an oligonucleotide antisense inhibitor of human DNA methyltransferase 1 , given as a 7-day infusion in patients with advanced solid tumors. Clin Cancer Res15: 3177-3183.

36. Claes B, Buysschaert I, Lambrechts D (2010) Pharmaco-epigenomics: discovering therapeutic approaches and biomarkers for cancer therapy. Heredity 105: 152-160.

37. Klisovic RB, Stock W, Cataland S, Klisovic MI, Liu S, et al. (2008) A phase I biological study of MG98, an oligodeoxynucleotide antisense to DNA methyltransferase 1 , in patients with high-risk myelodysplasia and acute myeloid leukemia. Clin Cancer Res 14: 2444-2449.

38. Hoshino I, Matsubara H (2010) Recent Advances in Histone Deacetylase Targeted Cancer Therapy. Surg Today 40: 809-815.

39. Winquist E, Knox J, Ayoub JP, Wood L, Wainman N, et al. (2006) Phase II trial of DNA methyltransferase 1 inhibition with the antisense oligonucleotide MG98 in patients with metastatic renal carcinoma: a National Cancer Institute of Canada Clinical Trials Group investigational new drug study. Invest New Drugs 24: 159-167.

40. Chanan-Khan AA, Borrello I, Lee KP, Reece DE (2010) Development of targetspecific treatments in multiple myeloma. $\mathrm{Br} \mathrm{J}$ Haematol 151: 3-15.

41. Camacho LH, Olson J, Tong WP, Young CW, Spriggs DR, et al. (2007) Phase I dose escalation clinical trial of phenylbutyrate sodium administered twice daily to patients with advanced solid tumors. Invest New Drugs 25:131-138, 2007.

42. Steensma DP (2010) Novel Therapies for Myelodysplastic Syndromes Hematol Oncol Clin N Am 24: 423-441.

43. Daud AI, Dawson J, DeConti RC, Bicaku E, Marchion D, et al. (2009) Potentiation 
Citation: de Almeida VR, Brunetto AL, Schwartsmann G, Roesler R, Abujamra AL (2011) De-mystifying the Epigenetic Free for All: Pharmacophore Modeling for Epigenetic Cancer Therapy. Pharm Anal Acta 2:102e. doi:10.4172/2153-2435.1000102e

of a topoisomerase I inhibitor, karenitecin, by the histone deacetylase inhibitor valproic acid in melanoma: translational and phase I/II clinical trial. Clin Cancer Res 15: 2479-2487.

44. Perry AS, Watson WG, Lawler M, Hollywood D (2010) The epigenome as a therapeutic target in prostate cancer. Nat Rev Urol 7: 668-680.

45. Zheng YG, Wu J, Chen Z, Goodman M (2008) Chemical regulation of epigenetic modifications: opportunities for new cancer therapy. Med Res Rev 28: 645-687.

46. Glaser KB (2007) HDAC inhibitors: clinical update and mechanism-based potential. Biochem Pharmacol 74: 659-671.

47. Li LC, Carroll PR, Dahiya R (2005) Epigenetic changes in prostate cancer: Implication for diagnosis and treatment. J Natl Cancer Inst 97: 103-115.

48. Walton TJ, Li G, Seth R, McArdle SE, Bishop MC, et al. (2008) DNA demethylation and histone deacetylation inhibition co-operate to re-express estrogen receptor beta and induce apoptosis in prostate cancer cell-lines. Prostate 68: 210-222.

49. Yoshida M, Kijima M, Akita M, Beppu T (1990) Potent and specific inhibition of mammalian histone deacetylase both in vivo and in vitro by trichostatin $\mathrm{A}$. J Biol Chem 265: 17174-17179.

50. Sharma D, Saxena NK, Davidson NE, Vertino PM (2006) Restoration of tamoxifen sensitivity in estrogen receptor-negative breast cancer cells: tamoxifenbound reactivated ER recruits distinctive co repressor complexes. Cancer Res 66: 6370-6378.

51. Hostetter CL, Licata LA, Keen JC (2009) Timing is everything: Order of administration of 5-aza-20-deoxycytidine, trichostatin A and tamoxifen changes estrogen receptor mRNA expression and cell sensitivity. Cancer Lett 275: 178184
52. Chai G, Li Ch, Zhou W, Wu L, Zhao Y, et al. (2008) HDAC inhibitorsact with 5-aza-20-deoxycytidine to inhibit cell proliferation by suppressing removal of incorporated abases in lung cancer cells. PLoS ONE 3: e2445.

53. Kummar S, Gutierrez M, Gardner ER, Donovan E, Hwang K, et al. (2007) Phase I trial of MS-275, a histone deacetylase inhibitor, administered weekly in refractory solid tumors and lymphoid malignancies. Clin Cancer Res 13: 54115417.

54. Gore L, Rothenberg ML, O’Bryant CL, Schultz MK, Sandler AB, et al. (2008) A phase I and pharmacokinetic study of the oral histone deacetylase inhibitor, MS-275, in patients with refractory solid tumors and lymphomas. Clin Cancer Res 14: 4517-4525.

55. Mercurio C, Minucci S, Pelicci G (2010) Histone deacetylases and epigenetic therapies of hematological malignancies. Pharmacological Research 62: 1834.

56. Gollob JA, Sciambi CJ, Peterson BL, Richmond T, Thoreson M, et al. (2006) Phase I trial of sequential low-dose 5-aza-20-deoxycytidine plus highdose intravenous bolus interleukin-2 in patients with melanoma or renal cell carcinoma. Clin Cancer Res 12: 4619-4627.

57. http://clinicaltrials.gov

58. Bradner JE, West M, Grachan ML, Greenberg EF, Haggarty SJ, et al. (2010) Chemical phylogenetics of histone deacetylases. Nat Chem Bio 6: 238-243.

59. Park JH, Jung Y, Kim TY, Kim SG, Jong HS, et al. (2004) Class I histone deacetylase-selective novel synthetic inhibitors potently inhibit human tumor proliferation. Clin Cancer Res 10: 5271-81. 